\title{
Influence of The Different Onion Varieties on the Population Density of the Main Insect Pests Infesting Onion Crop in Kafr EI-Shekh Region. \\ Awadalla, S. S. ${ }^{1}$; A. A. Taman ${ }^{2}$ and A. A. Aboria ${ }^{2}$ \\ 1 Economic Entomology Department, Faculty of Agriculture, Mansoura University, Mansoura, Egypt \\ 2 Field crop Insect Pest Department, Plant Protection Research Institute, Agricultural Research Center, Sakha, Egypt.
}

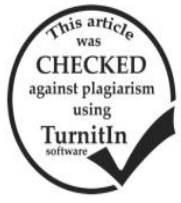

\begin{abstract}
The current experiments were carried out in the Research Farm of the Agricultural Research Station in Sakha, Kafr El Sheikh Governorate, where three main onion varieties (Giza 6, Giza 20 and Giza Red) were cultivated, during 2013/14 and 2014/15 seasons, to study the influence of different onion varieties on the population density of the most important insect pests. The highest populations of all investigated insects were recorded on variety Giza 6 followed by Giza 20 and Giza Red during the two-successive season. This study showed that the highest average numbers of the onion thrips Thrips tabaci Lind. on Giza 6 were $316.6 \pm 36.6$ and $286.4 \pm 34.1$ nymphs during the first and second season, respectively. The highest average number of the onion aphid Aphis gossypii Glov was also recorded on Giza 6 and represented by $1124 \pm 22.4$ and $1061 \pm 18.7$ individuals, during the first and second season, respectively. The highest average numbers of the Onion maggot Dalia allairia Fonseca was also recorded on Giza 6 and represented by $37.7 \pm 7.6$ and $41.3 \pm 8.5$ during the first and secon season, respectively. The onion varieties showed significant differences in their attraction to T. tabaci and A. gossypii, but not for D.allairia. For the Integrated Pest Management strategy for onion crop, Giza 6 has to be excluded from the approach of crop breeders and farmers due to its higher susceptibility for infestation.
\end{abstract}

Keywords: Aphis gossypii, Thrips tabaci. Dalia allairia, attraction, susceptibility, Integrated Pest Management,

\section{INTRODUCTION}

In Egypt, Onion (Allium Cepa L.) is an important field crop for both local consumption or for exportation. According to statistics of Ministry of Agriculture and Land Reclamation, the total area cultivated with onion crop in 2006 exceeded 80 thousand feddans produced over 950 thousand tons of onion bulbs (Mahmoud, 2008).

For integrated pest management program needs evaluation of the influence of some agricultural practices as planting dates and Onion varieties (Brar et al.,1993; El-khayat et al., 1997; Duchovskiene et al 2006 and Ruidar,2015). Because of genetic variation on Onion varieties, thus, the resistant varieties could be used as an item in IBM Program. Also, a few information is available on the influences of the different Onion varieties on the population density of the main insect pests (Nawaz et al.2003; Logos et al 2004; Alimousavis, 2007 and Jhon Diaz et al. 2012).

Therefore, the present experiments were carried out to study the influences of different Onion varieties during two successive seasons 2013/14 and 2014/15 in kafr-el shekh region.

\section{MATERIALS AND METHODS}

The current experiments were carried out in the Research Farm of the Agricultural Research Station in Sakha, Kafr El Sheikh governorate, where three main onion varieties Giza 6, Giza 20 and Giza Red were cultivated (during 2013/14 and 2014/15 seasons). This study was conducted to study the effect of Onion varieties on the main insect pests. Plants were transplanting in 6 January for each season. Three Onion cultivars namely, Giza 6, Giza 20 and Giza Red were obtained from Agriculture Research Station the Two successive seasons 2013/14 and 2014/15 in Kafr Elshekh Region. These experimental areas about $600 \mathrm{~m}^{2}$ each Variety was about $200 \mathrm{~m}^{2}$ divided into four replicates, each replicate was $50 \mathrm{~m}^{2}$ replicates arranged in Completely Randomized Design. Each plot consisted of 5 rows wide and $10 \mathrm{~m}$ long with $10 \mathrm{~cm}$ within rows and five $\mathrm{cm}$ between plants. No pesticides were applied in the plots during the experiment throughout the two seasons. Normal agricultures treatments were followed. Data on insect pests population were collected weekly from 10 randomly selected plants in each plot after one week from transplantation according to Hussain (1998) were taken early. Random plants were cut at the morning from base at weekly intervals and placed in plastic bag for counting in the laboratory by using stereoscopic- binocular and continued until the harvesting time of the crop.

The data obtained were analyzed using One-way ANOVA, and the Means were compared using Duncan's Multiple.

\section{RESULTS AND DISCUSSION}

The onion thrips (Thrips tabaci).

Data represented in Fig. (1) showed the total number and percentage of $T$. tabaci during the two successive seasons 2013/14 and 2014/15. The highest average number and its percentage of $T$. tabaci was recorded on Giza 6 and represented by 6331 individuals (36\%) and 5724 indiv (37\%) during the first and second season, respectively. While the lowest average number and its percentage was recorded on Giza Red which represented by 5799 indiv (33\%) and 4726 indiv (31\%) during the first and second season, respectively.

Data presented in Table (1) indicated that the highest numbers of T. tabaci were recorded on Giza 6 with average of $316.6 \pm 36.6$ and $286.2 \pm 34.1$ indiv during the first and second season, respectively. While, the lowest average number of T. tabaci was recorded on Giza Red with an average number of $278.2 \pm 30.1$ and $247.6 \pm 29.2$ during the first and second season, respectively.

Statistical analysis revealed that there were significant differences among onion varieties in the numbers of $T$. tabaci during both seasons of study. 


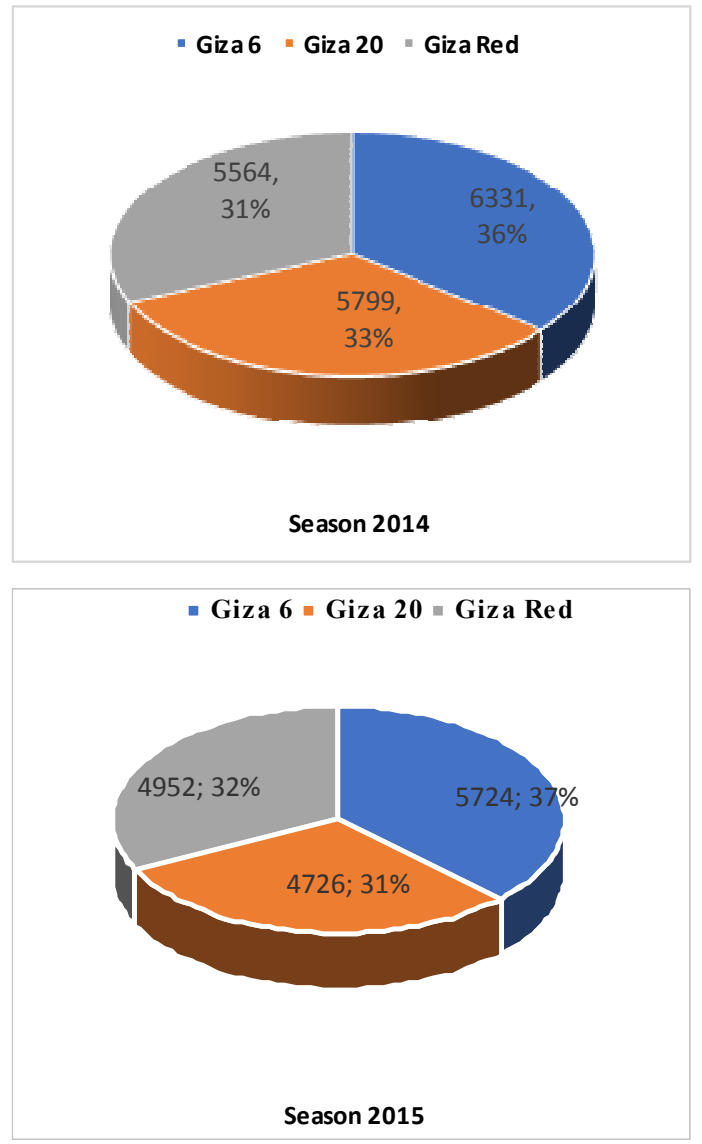

Fig. 1. The total number and percentage of $T$. tabaci on different varieties during the first $(2013 / 14)$ and second $(2014 / 15)$.

Table 1. The number $( \pm \mathrm{SE})$ of $T$. tabaci on varying onion varieties during the first (2013/14) and second $(2014 / 15)$ in Kafr El-Shekh Governorate.

\begin{tabular}{lcc}
\hline Varieties & $\begin{array}{c}\text { Season } \\
\mathbf{2 0 1 3 / 1 4}\end{array}$ & $\begin{array}{c}\text { Season } \\
\mathbf{2 0 1 4} / \mathbf{1 5}\end{array}$ \\
\hline Giza 6 & $316.6 \pm 36.6 \mathrm{a}$ & $286.2 \pm 34.1 \mathrm{a}$ \\
Giza 20 & $289.9 \pm 31.1 \mathrm{~b}$ & $236.3 \pm 29.2 \mathrm{c}$ \\
Giza Red & $278.2 \pm 30.1 \mathrm{~b}$ & $247.6 \pm 29.2 \mathrm{~b}$ \\
\hline
\end{tabular}

In a Colum means followed by the same letter are not significantly different at the $5 \%$ probability.

The onion Aphid (Aphis.gossypii).

Data represented in Fig. (2) showed the total number and percentage of A.gossypii during the two successive season 2013/14 and 2014/15. The highest total number and its percentage of A.gossypii was recorded on Giza 6 variety and represented by 2248 indiv (40\%) and 2122 indiv (42\%) during the first and second seasons respectively. While the lowest total number and its percentage was noticed on Giza Red which represented by 1662 indiv (29\%) and 1422 indiv $(28 \%)$ during the first and second season respectively.

Data presented in Table (2) indicated that the highest average number of A.gossypii were recorded on Giza 6 with average of $112.4 \pm 22.4$ and106.1 \pm 18.7 individuals during the first and second seasons. while, the lowest average number of A.gossypii was recorded on Giza Red Varity with an average number of 83.1 \pm 18.7 and $71.1 \pm 15.7$ during the first and second season respectively.

Statistical analysis revealed there were significant differences among Onion varieties in number of A.gossypii during both season study.

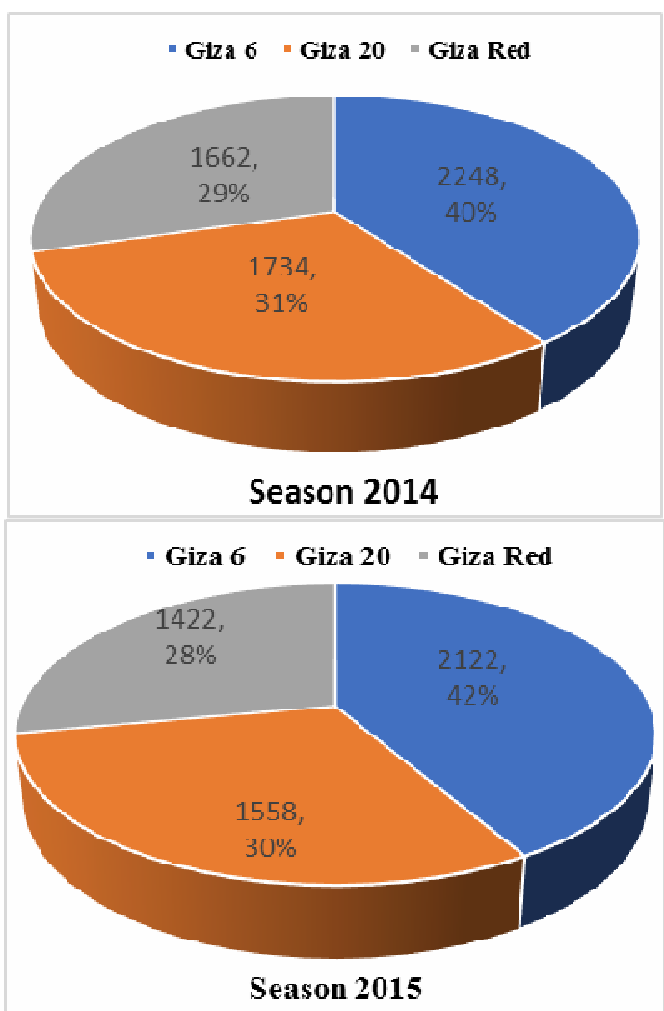

Fig 2. Total number and percentage of $A$.gossypii in different varities during seasons 2013/14 and 2014/15 in Kafr El-Shek Region.

Table 2. The number $( \pm \mathrm{SE})$ of $A$.gossypii on varying onion varieties during the first $(2013 / 14)$ and second (2014/15) in Kafr El-Shekh Governorate.

\begin{tabular}{lcc}
\hline Variety & Season 2013/14 & Season 2014/15 \\
\hline Giza 6 & $112.4 \pm 22.4 \mathrm{a}$ & $106.1 \pm 18.7 \mathrm{a}$ \\
Giza 20 & $86.7 \pm 18.1 \mathrm{~b}$ & $77.9 \pm 14.6 \mathrm{~b}$ \\
Giza Red & $83.1 \pm 18.7 \mathrm{~b}$ & $71.1 \pm 15.7 \mathrm{~b}$ \\
\hline
\end{tabular}

In a Colum means followed by the same letter are not significantly different at the $5 \%$ probability.

The onion pulb (Dalia.alliria).

Data represented in Fig. (3) showed the total number and percentage of D.alliria during the two successive season 2013/14 and 2014/15. The highest total number and its percentage of D.alliria was recorded on Giza 6 variety and represented by 754 indiv $(40 \%)$ and 825 indiv (36\%) during the first and second seasons respectively. While the lowest average number was noticed on Giza Red and represented by 559 indiv $(29 \%)$ and 723 indiv (31\%) during the first and second season seasons, respectively.

Data presented in Table (3) indicated the average number of D.alliria which attacking onion varieties during 2013/14 and 2014/15 seasons. the highest 
average number of D.alliria was recorded on Giza 6 variety with average number $37.7 \pm 7.6$ and $41.3 \pm 8.5$ individuals during the first and second seasons respectively. While, the lowest average number of D.alliria was recorded on Giza Red Varity with an average number of $27.9 \pm 6.6$ and $36.2 \pm 7.8$ during the two seasons, respectively.

Statistical analysis revealed that there were insignificantly differences among Onion varieties and D.alliria during both season study.

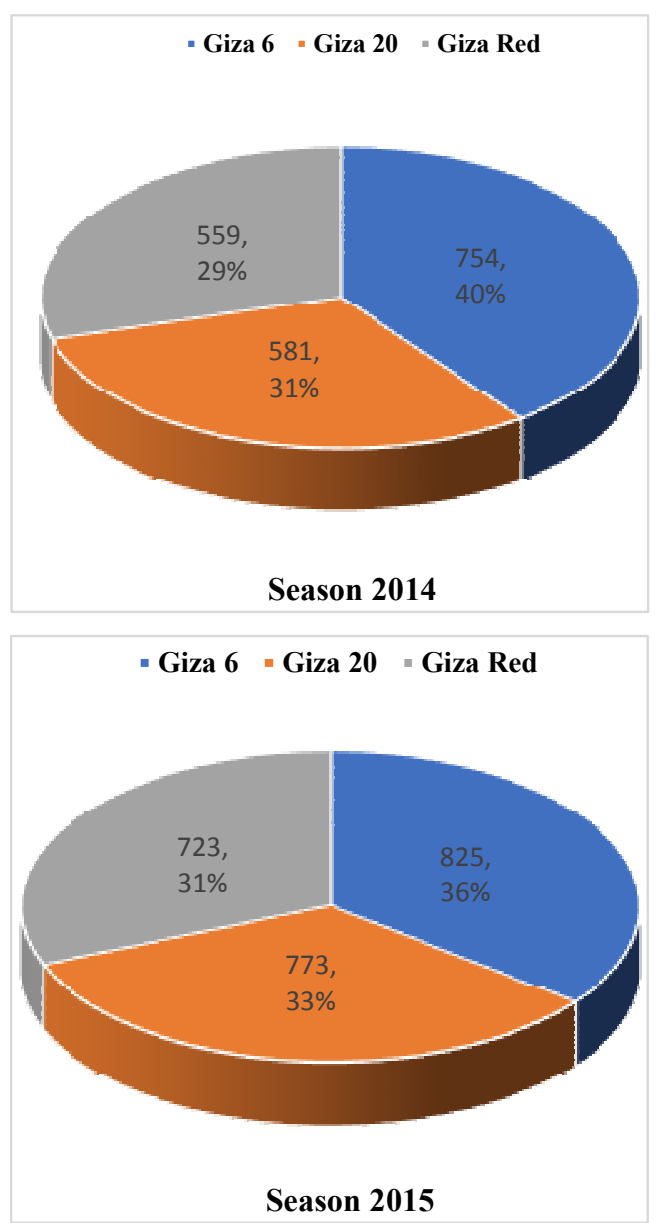

Fig 3. Total number and percentage of D.allairia in different varities during seasons 2013/14 and 2014/15 in Kafr El-Shek Region.

Table 3. The number $( \pm \mathrm{SE})$ of D.allairia on varying onion varieties during the first $(2013 / 14)$ and second (2014/15) in Kafr El-Shekh Governorate.

\begin{tabular}{lcc}
\hline Variety & Season 2013/14 & Season 2014/15 \\
\hline Giza 6 & $37.7 \pm 7.6 \mathrm{a}$ & $41.3 \pm 8.5 \mathrm{a}$ \\
Giza 20 & $29.1 \pm 6.5 \mathrm{a}$ & $38.7 \pm 7.9 \mathrm{a}$ \\
Giza Red & $27.9 \pm 6.6 \mathrm{a}$ & $36.2 \pm 7.8 \mathrm{a}$ \\
\hline
\end{tabular}

In Colum means followed by the same letter are not significantly different at the $5 \%$ probability.

The results are in agreement with those of Salman, 2000 who showed significant deference between all onion variety of were liable to infestation by T. tabaci and D.alliria. the onion variety shandweel 1 demonestrated the highest infestation recordeds, meanwhile Giza 20 variety showed the least parameter El-Khayat et al. (1997) who showed significant deference between three planting dates in the numbers of the main insect pests attacking Onion variety in Egypt. Coudriet et al, 1979 found that the onion cultivar 'Nebuka' had 48, 72, and 67\% fewer adult onion thrips, T. tabaci Lindeman, caught on sticky-card traps than cultivars; Texas Early Grano 502, Tenas Early Grano 951 and creoler, respectively, Nawaz et al. 2003 Local kandhari varaity followed by sariab surkh were the most susceptible to thrips infestation while chiltan -89 was the least. Kalafchi et al. 2006 they found that significant differences were observed between cultivars in terms of the population density of the onion thrips. The highest population density of thrips was observed in cv. (Azarshahr) whereas cultivars Ghome, Kashan, Kavar, Abarkooh and yellow sweet Spanish recorded low population of thrips.

\section{REFERENCES}

Alimousavis, A.; M.R. Hass and Okht and Moharramipowr (2007). Evaluation of Iranian onion cernplasms for resistance to thrips. International J. Agric. and Biol. 9 (6) 897-900.

Brar, K. S.; A.S. Sidhu; and M.L. Chadha, (1993). Screening onion varieties for resistance to Thrips tabaci Lind. and Helicooverpa armigera (Hubner). J. of insect sci. 6 (1):123-124.

Coudriet, D. L.; A.N. Kishaba; J. D. Mccreight and G.W. Bohn, (1979). Varital resistance in onions to Thrips. J. Econo. Entomol., 72 (4): 614-615.

Cohort Software (2004). Costat. www.cohort .com montery, California,USA.

Duchovskiene, L. (2006). The abundance and population dynamics of onion thrips [T. tabaci] in leek under filed conditions. Agrono. Res. 4[ special issue], 163-166.

El-Khyat, E. F.; F. F. Shalaby; F.M. Lotfy; A.R. Ibrahim (1997). Thrips infestation to onion plants in relation to onion variety, planting date and nitrogen fertilization. Annals of Agric. Sci. moshtohor; 35(3):1761-1777.

John Diaz-Montano, Jozsef Fail, Mark Deutschlander, Brian A. Naultnand, M. Anthony (2012). SHELTON Characterization of Resistance, Evaluation of the Attractiveness of Plant Odors, and Effect of Leaf Color on Different Onion Cultivars to Onion Thrips (Thysanoptera: Thripidae) J. Econ. Entomol. 105(2): 632Đ641.

Kalafchi, M.; M. Mobli; R. Ebadi, and A. M. Rezaei, (2006). A study of population of onion thrips (T. tabaci Lind.) and its effect on bulbing and yield of selected onion cultivars in Isfahan. Iranian J. of Agric. sci. 36:6, pe1477.

Loges, v; M. A. Lemos,; L. v. Resende,; D. Menezes, ; V. F. Santos, (2004). Thrips resistance in onion cultivars and hybrids. Horti., - Brasileira. 22 (2):222-225. 
Mahaffey, L. A. and W. S. Cranshaw, (2010). Thrips species associated with in Colorado. Southwestern Entomolo. 35:1,45-50.

Mahmoud, H. H. (2008). Ecological Studies on certain insect pests of onion with special emphasis on the onion bulb fly Eumerus anoenus Loew. Ph.D. Thesis, Fac., Agric.,Cairo Unvi, Egypt.

Nawaz, M.; M. F. Malik and Z. Hapeez (2003). Evalution of promising onion [Allium cepa] varieties against Thrips infestion in the AgroEcosystem of Balochistan, Pakistan-I. Asian J. Plant Sci., 2 (9): 716-718.

Salman, A. M. A. (2000). Relative susceptibility of certain onion varieties to the infestation of the onion Thrips Tabaci (lind) and the Onion maggot,Delia alliria(Meigen) in Upper Egypt.J. Agric. Sci. Mansoura Univ.,25(1):469-473.
Shakeel, M.; T. Mehmood; K.M. Khokhar (2006). Host plant resistance of promising onion [ Allium cepa] varieties against onion thrips $T$. tabaci Lindeman. Sarhad- J. Agric.; 22[3]:477-479.

Ruidar Ali Shah, Imtiaz Ali Khan (2015). Evaluation of onion cultivars against onion thrips, Thripstabaci (Lindeman) infestation on onion cropJournal of Entomology and Zoology Studies.; 3 (2): 121123.

Szwejda, J. (2005). Pests threatening onion in Poland. Nowosci- Warzwniczy, 40:53-59.

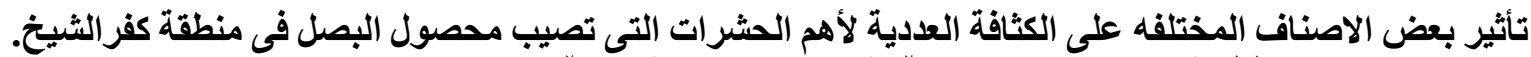

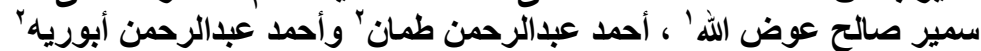

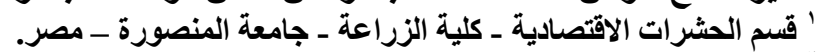

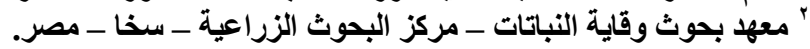

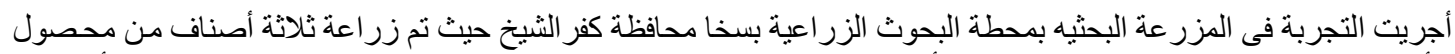

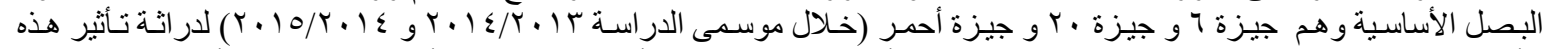

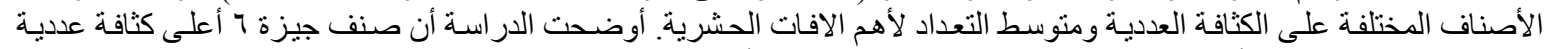

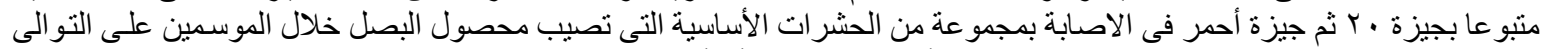

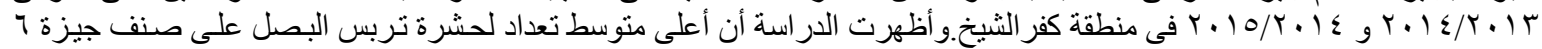

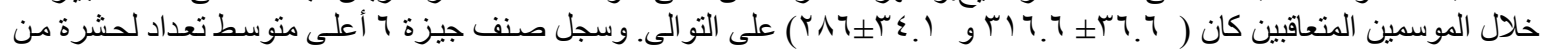

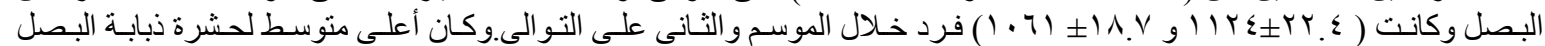

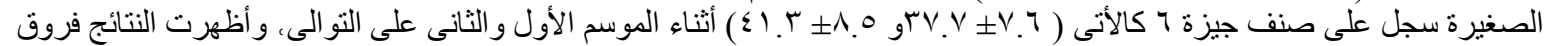

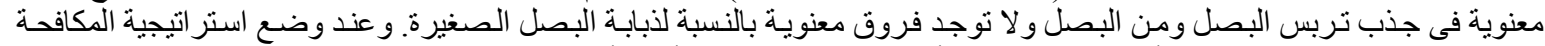
المتكاملة لمحصول البصل ير اعى أن الصنف جيزة 7 أكثر حساسية للاصابة بأهم الأفات الحشرية.
} 